\title{
The southern river otter (Lontra provocax): insights from the perspective of Andean Patagonian ethnozoology
}

\author{
Carla Pozzi ${ }^{1}$ and Ana H. Ladio ${ }^{1, *}$
}

\begin{abstract}
Animals play a significant role in many cultures around the world. The southern river otter Lontra provocax (known locally as the "huillín") is endemic to southern Argentina and Chile, and is currently in danger of extinction. Mapuche communities have always lived closely alongside their animal resources, generating unique bonds with them. The objective of this work is to obtain an overview of the importance given to this species in the literature of the region with regard to the nature-culture connection. A systematic bibliographical review was carried out using reference libraries and web browsers. From all the sources analysed, 110 were selected which held biocultural information. The main approach used was ecological; however, the ethnohistorical texts provided the richest information on the bond between this otter and humans. The Mapuche name "huillín" appears in all the publications analysed, showing its continuity over time. Of all the zootoponyms found, $87.5 \%$ were Chilean and $12.5 \%$ were Argentine. The Argentine case is found in Nahuel Huapi lake, and is worthy of note as its name could involve the huillín. The results of this work increase our knowledge of the biocultural heritage of our region, and enable us to reflect on the associated historical and political processes.
\end{abstract}

Keywords: Ethnohistory; Origin; Name; Mapuche; Fauna.

1 Departamento de Conservación y Educación Ambiental, Parque Nacional Nahuel Huapi. Av. San Martin 24, 8400 Bariloche, Rio Negro, Argentina.

2 INIBIOMA, CONICET-Universidad Nacional del Comahue. Quintral 1250, 8400 San Carlos de Bariloche, Río Negro, Argentina.

* Corresponding author $\bowtie$. E-mail address: AL (ahladio@gmail.com), CP (carlapozzi@gmail.com)

\section{SIGNIFICANCE STATEMENT}

Our systematic review provides little-known aspects from the huillín (Lontra provocax) ethnozoology, an otter endemic to Patagonia. The origin of its name in the Mapuche language and its persistence until our days, provides important ethnohistorical data to understand the link between the species and humans. The results of our work allow us to make visible the biocultural heritage of our region and reflect on the associated historical and political processes. 


\section{INTRODUCTION}

The study of the nature-culture connection focuses on the relationship constructed by human beings with all that surrounds them (Martínez 2009). In the case of American cosmologies, this relationship is a close bond where Nature is not separate from everyday cultural practices, and it is constructed mutually, through processes of coevolution (Levy-Strauss 1972; Descola 1996).

Animals play a significant role in human cultures around the world, and even in human existence itself. In day to day life they are present as part of our heritage, both tangible - related to our food, medicines, clothing, economy, recreation and company, and intangible - artistic expression, legends, and myths. They are important due to their ecological value and because they are so deeply rooted in many of the symbolic, spiritual and cultural schemas of human cultures (Posey 1999; Fita et al. 2009; Hermann et al. 2013). In particular, the ways in which animals are named, counted, and described within local languages reflect the strength of this Nature-Culture bond (Vargas and Urrutia 2004). Language is the medium used by social groups to develop and interchange their perceptions and interpretations of reality, and their agreement or dissent (Di Caudo 2016).

Little is known about the variety of interactions (past and present) human societies have maintained with animals as part of their biocultural heritage (Alves and Souto 2010). In this work we focus on the "huillín" (Lontra provocax), which inhabits Argentine and Chilean Patagonia (Figure 1); this otter has not yet been studied using an ethnobiological approach. We are particularly interested in the Local Ecological Knowledge (LEK) registered on this animal up to the present time. LEK has been defined as "a cumulative body of knowledge, practices and beliefs associated with the relationship between human beings and their environment, which evolves by means of adaptive processes and is transmitted culturally from one generation to the next (Berkes et al. 2000). LEK conveys the etymology of animal names and classifications over time, showing the significance of animal species for human populations.

The huillín is endemic to the south of Argentina and Chile, and is currently in danger of extinction (IUCN; Sepúlveda et al. 2015). This amphibious mammal, adapted for swimming, inhabits fresh and salt water systems. Its body is hydrodynamic, with a dorsoventrally flattened head, very short legs and interdigital membranes on the front and back paws (Lariviére 1999). This species can measure up to 1400 $\mathrm{cm}$ in length including the tail, and its weight may reach $15 \mathrm{~kg}$ (Lariviére 1999; Sepúlveda et al. 2007). The only stable freshwater population known in Ar- gentina is found in northern Patagonia, where it inhabits lakes, rivers, streams and lagoons in areas of the Andean-Patagonian forest and the steppe, with narrow, sandy or rocky coasts where there are exposed roots and good plant cover (Chehébar 1985; Medina 1996; Medina-Vogel et al. 2003; Medina-Vogel and Gonzalez-Lagos 2008; Sepúlveda et al. 2009). The huillín is the "top predator" of the aquatic systems of this area. Animals are so called when they prey on others, but are not themselves preyed on by any other animals; they are at the top of the food pyramid, controlling the abundance and dynamics of the food chain (Kruuk 2006; Mason \& Macdonald 2009; Chehébar and Ramilo 1992). The scientific epithet provocax (Thomas 1908) comes from the Latin meaning to provoke: to call out, provoke, challenge (Mouchard 2019).

According to several authors (Chehébar 1985; Chehébar et al. 1986; Chehébar and Benoit 1988; Chébez 1994; Fasola et al. 2006), during the $19^{\text {th }}$ and the beginning of the $20^{t h}$ centuries the huillín was much hunted in order to satisfy the demands of the fur industry, causing it to be registered as "in danger of extinction". This situation led to an $80 \%$ decrease in its original distribution, and it is now restricted to three isolated population nuclei: the southern region of the Limay river basin, the Beagle Channel and Staten Island (Fasola 2009).

According to archaeological, ethnohistorical and recent records, Mapuche communities have long lived alongside their animal resources, generating unique bonds with them. These communities have been characterised by their mobility in search of animals to hunt, fish and gather (Miotti and Salemme 2004; Hartmann Navarro 2016). In this context Villagrán (1999) described the rich zoological nomenclature of Mapudungun, the language of the Mapuche people, or "the people of the land" (from "mapu" meaning land, and "che" meaning people, or person). Mapudungun is an Andean language, related to other languages from Patagonia and the central Andes (Malvestitti 2005). The number of active speakers is estimated to be between 100.000 and 200.000, and the number of passive speakers is thought to be approximately 100.000 more. This language has influenced the Spanish spoken in its distribution area, and at the same time, it has incorporated Spanish and Quechuan words (Hartmann Navarro 2018).

The integration of the animal world into the Mapuche cosmovision is very obvious in the symbolic representations of some animal groups (principally reptiles, birds and mammals) that appear in their myths and stories (Villagrán 1999; Aigo and Ladio, 2016). Names given to the geographical environment (zootoponyms) and the mention of animals in the nicknames of individuals show the closeness of this bond (Villagrán 1999). In addition, Mapuche lineages very often 


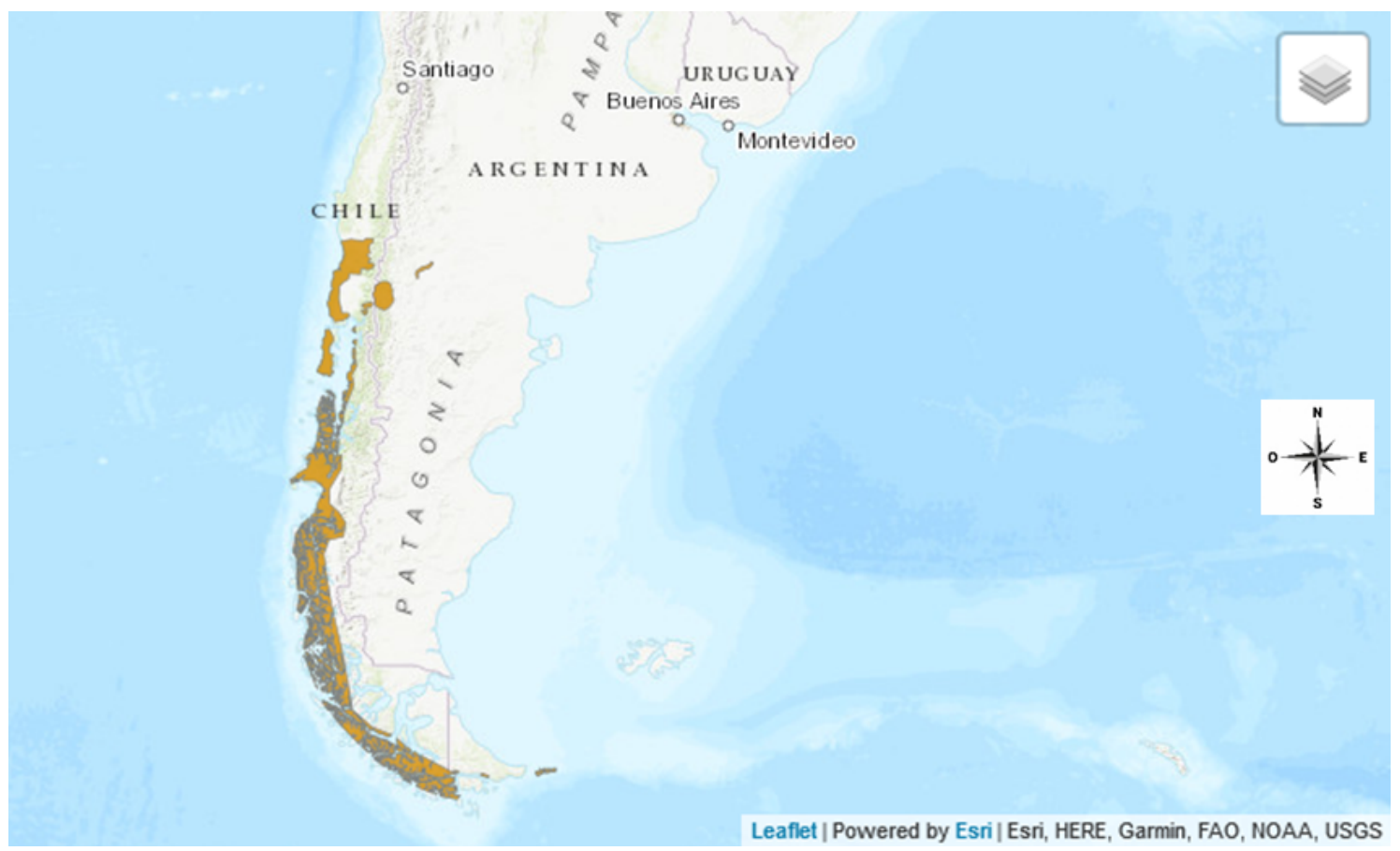

Figure 1. Current distribution of the huillín (Lontra provocax) in Argentina and Chile. Areas where the species is present are shown in ochre colour (UICN 2015).

have animals as totems (mythical ancestors), which is reflected in the person's surname (heritage) (Villagrán 1999). The profound knowledge Mapuche people have of their surroundings translates into an extensive ethnobiological vocabulary, which has been recorded by chroniclers and researchers over decades, and corroborated today (Hartmann Navarro 2018). According to Castillo and Ladio (2017) and other authors (Prates 2009; Vilela et al. 2009), members of the Mapuche community maintain relationships of reciprocity and equality with animals, engaging in dialogue with them through their ancestors and the forces of nature. Rozzi (2004; 2016), reported that this type of action can only be carried out through Mapudungun. This language, according to its speakers, has the ability to listen to the earth and convey its messages in an onomatopoeic way, poetically, and in great detail with respect to the ecosystem.

The objective of this work is to obtain an overview of the significance of the huillín in regional literature, in relation to the Nature-Culture connection. Through analysis of written sources and from an ethnobiological perspective, the LEK and role assigned to the species was studied, as well as the origin, significance and interpretation of its common name. Furthermore, the huillín was studied in terms of zootoponymy and heritage. Our results have enabled us to discuss the contribution of this kind of approach to the biocultural conservation of faunistic resources.

\section{MATERIAL AND METHODS}

\section{Qualitative analysis of written sources}

Systematic review of texts was carried out using web browsers (Scopus and Google Scholar) with the following key words: huillín, güillín, tigre de agua (common names), Lontra provocax, Lutra huidobra and Castor huidobrius (its current scientific name and two previous synonyms). Local and regional reference libraries were also consulted (Universidad de Rio Negro, Grupo de Etnobiología, Museo de la Patagonia). As a result, very diverse sources were obtained, written in scientific and non-scientific language (texts written by travellers, for example), in old and modern Spanish. Bibliographical analysis was based on the initial interpretation of 759 texts (Medeiros 2009), which were then submitted to selection and inclusion criteria (Figure 2). Only texts that contributed aspects associated with LEK on the species were included.

\section{Data analysis}

All the texts were submitted to discourse analysis techniques, beginning with the general information (date, location of the work, authors, place of publication, etc.). In order to systematize the information, the texts were classified a posteriori into "type of source", depending on whether it was a scientific publication (paper, thesis, conference presentation, 


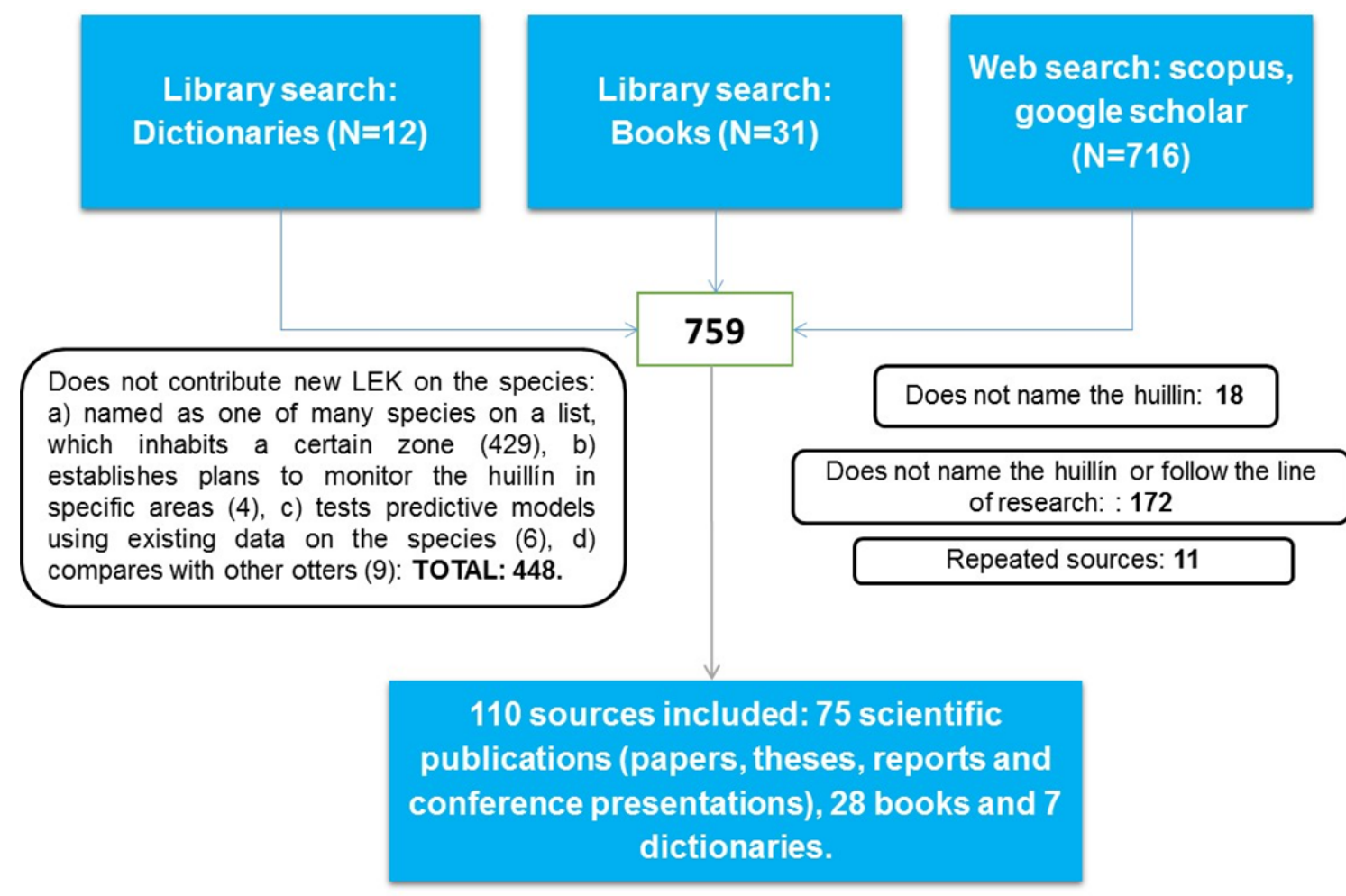

Figure 2. Diagram showing the sources of information found and selected which referred to the huillín.

etc.), book or dictionary. They were also organized according to "type of approach", based on whether they were ecological, veterinary, genetic, palaeontological, ethnozoological, ethnohistorical, nomenclatural or related to hunting.

In the case of "type of approach", ethical descriptions were developed from the emic ones found in the texts reviewed. It should be pointed out that the emic focus consists in "the vision from within the society"; that is, it reflects phenomena from the perspective of the reality of the culture itself (Pike 1954; Frake 1969).

The relationship between source and approximation types was analyzed with a RAWGraphs alluvial diagram (Mauri et al. 2017). Alluvial diagrams allow to represent flows and to see associations between categorical dimensions, visually linking to the number of elements sharing the same categories. It is useful to see the evolution of cluster (such as the number of publications belonging to a specific group). In addition, we used generalized Linear Model (GLM) considering a Poisson distribution, in order to test the influence of the independent variables (type of approximation and type of sources) on the count of publications (response variable). We only included main effects in the model, and chose Type III analyses and the Wald $\mathrm{chi}^{2}$-statistics. The analyses were performed using IBM SPSS.

The texts were subjected to a critical review, breaking down the information of interest and classifying it. Hermeneutic analysis of the texts was also performed, considering the accuracy of the information and the historical and philosophical context of the primary authors (Medeiros 2014).

Finally, to complete the analysis of the origin of the name, we consulted key people belonging to the Mapuche Educational Centre of Neuquén (Centro Educativo Mapuche de Neuquén [CEMN]) and linguistics experts from the Institute of Research on Cultural Diversity and the Process of Change (Instituto de Investigaciones en Diversidad Cultural y Proceso de cambio [IIDYPCA]).

\section{RESULTS AND DISCUSSION}

\section{General overview of existing literature on the huillín}

From all the sources analysed, 110 were chosen: 75 scientific publications (papers, theses, reports and conference presentations), 28 books and 7 dictionaries. The alluvial diagram showed that the different types of sources include different types of approaches, where the ecological approximation was predominant and the ethnozoological was scarcely addressed (Fig. 3 ). With regard to "type of source", papers are broad in approximations, as well, books and chapters that described aspects of the huillín from diverse "types of 
approach": ecological (57\%), ethnohistorical (25\%), nomenclatural (14\%) and ethnozoological (4\%) (Figure 3). We have found that the counts of publications are influenced by the type of approach and the type of source (Figure 3, GLM, $p<0.05$ ). The main types of source dealing with this species were scientific papers $(49 \%$, GLM $p<0,05)$ and books $(25 \%$, GLM $p<0,05)$. The predominant type of approach in the texts was ecological $(65 \%$, GLM $p<0,05)$, the rest of types of approximation were not significant in the model: nomenclatural (14\%), veterinary (6\%) and ethnohistorical $(6 \%)$, etc. revealing the scientific interest that this species has aroused in the ecological sciences (Figure 3).

Considering papers, the main scientific journals were Biological Conservation, Journal of Zoology and IUCN Otter Specialist Group Bulletin. The first scientific work on this species using this approach was published in 1908 by Thomas, and the most recent was published in 2018 by Cianfrani and collaborators. The huillín has been the subject of theses in the fields of ecology and ethnozoology (11 theses, 1\%) and its name appears in regional dictionaries of the Mapuche language (7 dictionaries, 0.6\%) (Figure 3).

The main subjects dealt with from an ecological "type of approach" refer to the physical characteristics of the species and its behaviour (Thomas 1908; Molina 1987; Chehébar and Martin 1989; Reyes Küppers 2007), aspects of its distribution (Chehébar 1985; Chehébar et al. 1986; Medina 1991; Porro and Chehébar 1995; Chehébar and Porro 1998; Aued et al. 2003; Carmanchahi et al. 2006; Fasola et al. 2006; Fasola 2009; Pozzi and Chehébar 2013), the characteristics of its habitat (Chehébar and Benoit 1988; Medina et al. 2003; Astorga et al. 2006; Sepúlveda et al. 2007; Medina and Gonzalez-Lagos 2008; RodríguezJorquera and Sepúlveda 2011), studies on its diet (Sielfeld 1984; Medina 1998; Fasola et al. 2006; Choupay 2006; Gonzalez-Lagos 2006; Gozzi 2008; Fasola 2009), the effect of the American mink (Neovison vison, an invasive exotic species) (Medina 1997; Cassini 1997; Fasola 2009; Gomez et al. 2010; Valenzuela 2010; Valenzuela et al. 2013; Medina et al. 2013), and its conservation status (Sielfeld et al. 1977; Chehébar 1986; Chehébar and Porro 1998; Sielfeld and Castilla 1999; Sielfeld 2006; Cassini et al. 2010; Valenzuela et al. 2011; Sepúlveda et al. 2015).

The ecological focus of most of the texts analysed could be due to the interest aroused historically by the study of otters in the northern hemisphere (Towei 1974; Melquist and Hornocker 1979; Melquist and Hornocker 1979; Melquist et al. 1981; Melquist 1982; Macdonald 1983; Macdonald and Mason 1983; Macdonald and Mason 1984; Macdonald and Mason 1985; Reid et al. 1986; Mason and Macdonald 1987), their charismatic behaviour (Hajek and Groenendijk 2001;
Mosquera-Guerra et al. 2015; Botello et al. 2006; Kruuk 2006; Calmé and Sanvicente 2009), and their severe overexploitation (Chanin and Jefferies 1978; Jefferies 1989; Shaler 1990; Mason and Macdonald 2009), which has been reflected in research interest. The books written by travellers and the dictionaries may also have inherited this interest in the species, since the travellers generally came from areas where otters are known and used.

\section{The relationship between the Mapuche people and the huillín, from an ethno- historical perspective}

Ethnohistorical texts provide the richest information on the relationship between the huillín and human beings. According to the sources analysed (Table $1)$ it is notable how $75 \%(n=6)$ of the cases of observation of this species have assigned a utilitarian value to it, principally in the form of providing humans with warm furs. The value of its pelt was recognized by the fur industry, and was the cause of local and regional extinctions of otters throughout the world (Chanin and Jefferies 1978; Jefferies 1989; Mason and Macdonald 2009).

In this type of literature, a health/medicinal value has also been assigned to the river otter, to treat ailments. On his journey through Argentine and Chilean Patagonia (1878), De Rosales writes, "their pelts are very warm, of great use for the headaches produced by the cold and to correct paralysis"... "...their bile makes marvellous eye drops against the clouds and cataracts of the eyes". In cities of Asia and China otters are used in traditional medicine, without specifying the ailment (Kruuk 2006). In India, Lutra perspillita blood is used for cases of epilepsy (Kruuk 2006; Nagulu et al. 1999). It has been found that in Brazil Lontra longicaudis is used against thrombosis (Costa Neto and Alves 2010; Alves and Alves 2011) and to cure blisters (Alves and Alves 2011). Lontra canadensis has also been cited as having medicinal uses but specific ailments were not specified (Alves \& Costa Neto 2011).

On the other hand, these books also highlight the fierceness of this river otter, which has certain physical and behavioural characteristics that frighten humans. In the first case, Molina (1987) refers to the species: "... the huillin is naturally fierce and brave, in such a way that it runs to steal fish from under the very noses of the fishermen..." In the second case, De Rosales (1878) recounts, ". . . it bites with such tenacity that it doesn't relax the pressure until you hear the sound of bones breaking..." and in the third case, while on a journey through Patagonia, Musters (2007) reports, ".. the Indians said it was impossible for a man to cross that river at its deepest part, past the fjord, be- 


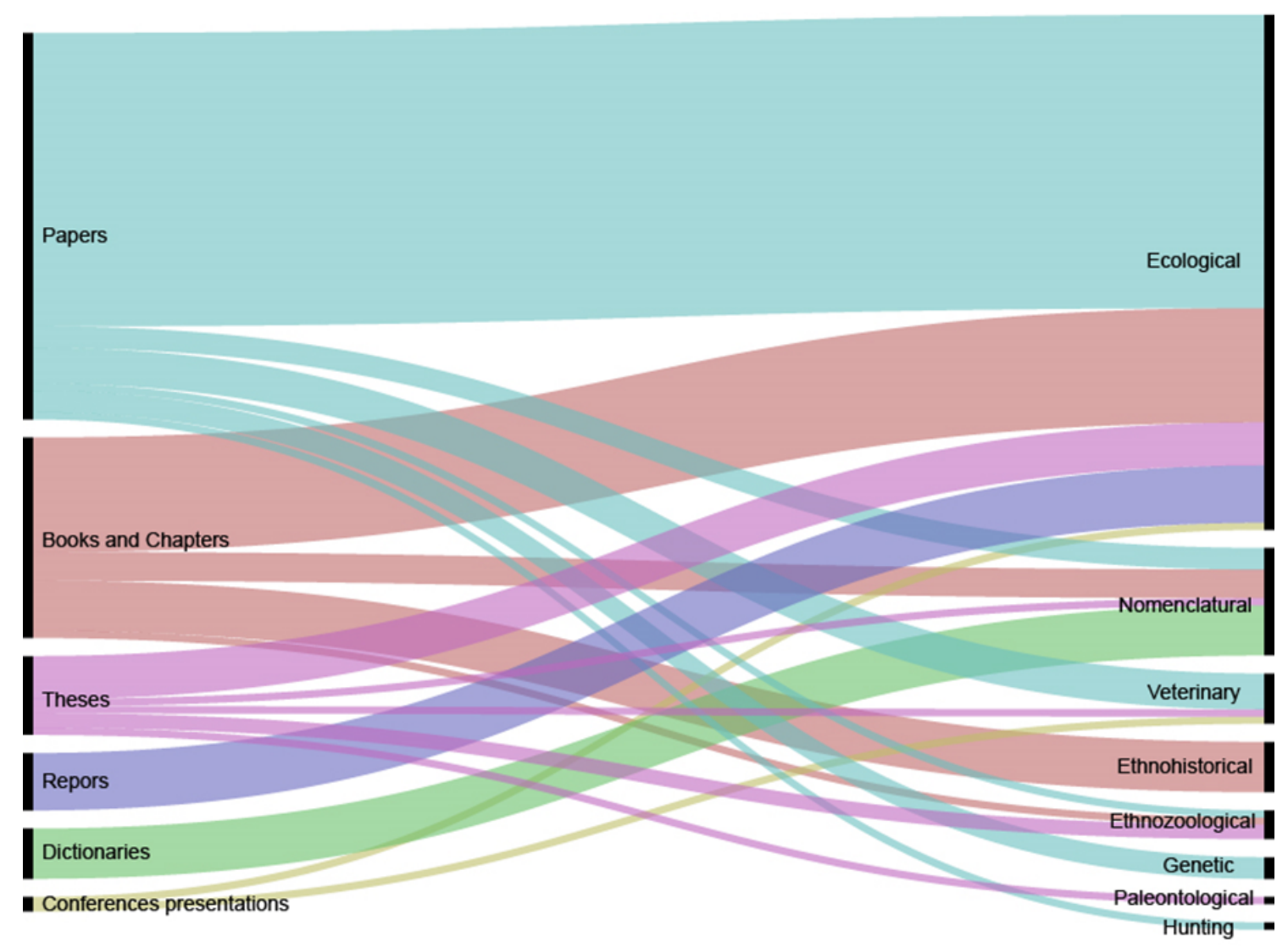

Figure 3. Alluvial diagram to represent flows and to see relationships between type of sources (left) and type of approach (right) categories, visually linking to the number of elements sharing the same categories. The long of dark bars in both sides represent the frequency of each category.

cause of some fierce animals they called "water tigers", which always attacked and ate anything in the river". These texts appear to show that the authors agreed with the locals as to the ferocity of the species, but also used human attributes such as bravery to describe them.

Few ecological details of the species are given in the ethnohistorical texts (Table 1). De Rosales (1850) writes "...it fishes and fills its caves with fish in a short time". This behaviour of storing its prey in caves has not been described up to now in the ecological bibliography published on this river otter. It would not be strange to think of this species having this behaviour, since it is known to eat fish and use large caves on the shores of the water bodies where it lives (Chehébar 1985; Medina 1991).
Ulloa (2001) suggests that western notions cannot accurately explain the ideas of other cultural systems, or the relationship they establish between humans and Nature. Nature is felt, conceptualized and constructed differently according to social processes based on moral and ideological convictions. In this sense, the ethnohistorical sources written by nonMapuche authors (Table 1) can show the strong connection between the Mapuche people and the river otter only partially, and in a biased way. The authors possibly based their writings on comments made by local inhabitants, and reinterpreted them according to their own logic. Nevertheless, having recognising the courage and the adept, feisty character of the otter, it is likely that these human attributes were valued by the authors and local inhabitants alike. 
Table 1. Ethnohistorical descriptions referring to the huillín in books. From the textual information found (emic description), etic descriptions were devised: U (utilitarian), B (behavioural) and/or TP (transfer of power).

\begin{tabular}{llll}
\hline$N^{\circ}$ Cite & Period & Textual Information \\
the information
\end{tabular}

\begin{tabular}{|c|c|c|c|c|}
\hline & & & & the information \\
\hline 1 & $\begin{array}{l}\text { Molina } \\
\text { (1987). }\end{array}$ & 1810 & $\begin{array}{l}\text { "...the first of them, which I had added to the Beaver because of the similarity of their } \\
\text { teeth, is around three feet in length, from the point of its lips to the start of its tail, and } \\
\text { two in height. The body has a double covering of fur: an inner one, finer and softer than } \\
\text { a rabbit's, and an outer one, much longer and courser; both are blackish on the back and } \\
\text { whitish on the belly. The short hair takes up black and turquoise colours very well, and it } \\
\text { really looks like velvet. Hats are made from it, which are just as good as the real Beaver } \\
\text { ones. The head of these animals is almost square, the ears are short and rounded, the eyes } \\
\text { small, the snout obtuse, the mouth adorned with four incisive teeth, two on the top and two } \\
\text { on the bottom, and sixteen molars; the four feet are divided into five toes, the front ones } \\
\text { having a small membrane and the rear ones being completely webbed;the back and tail of } \\
\text { the animal are long, the latter hangs down and is densely covered with hair; in their groins } \\
\text { there is no liquid like that found in the Beaver. It is found in the deepest spots of rivers } \\
\text { and lakes, where it remains for long periods of time without having to come up to breathe, } \\
\text { since it has the foramen oval of the heart rather open, like seals. It feeds on fish and crabs; } \\
\text { then it goes to a certain site to deposit its faeces at the waterside, as cats do. Piles of this } \\
\text { excrement can be seen around these rivers. Hunters, guided by this observation, wait there } \\
\text { until nightfall, when the animal comes to the site to defecate, and in that position, they kill } \\
\text { it. The huillin is naturally fierce and courageous - even running to steal fish from under } \\
\text { the very noses of the fishermen. In this characteristic they differ from the Beaver, which, } \\
\text { it is said, does not like to eat fish. The female gives birth to two or three offspring, and in } \\
\text { my opinion, gestation lasts no more that five months. Sonnini wanted this animal to be an } \\
\text { Otter; I am not against this, because its generic characters are not decided by the number } \\
\text { of teeth, despite its form being quite different from that of the Otter." }\end{array}$ & $\mathrm{U} / \mathrm{B}$ \\
\hline 2 & $\begin{array}{l}\text { Cox } \\
(2005) .\end{array}$ & $1862-1863$ & $\begin{array}{l}\text {..."Suddenly I was surprised by the screams of a peon who had gone looking for water (..) } \\
\text { we ran to the shore and saw two black balls floating on the water, which seemed to belong } \\
\text { to amphibians; they were completely the heads of two otters that had been disturbed in } \\
\text { their aquatic appointment by the honest Pedro, and that having thrown themselves into the } \\
\text { water, they allowed themselves to be carried away by the current. With cold blood and a } \\
\text { fearlessness worthy of praise, Pedro threw himself into the water, armed with a stick; one of } \\
\text { the otters came out to rest on a small tongue of sand; there a singular combat (...). The otter } \\
\text { wanted to bite Pedro's calves, he gave him sticks; finally the stunned animal was motionless. } \\
\text { (..) We begin the inspection of the animal. The hair was ashy gray, it measured from the } \\
\text { head to the end of the tail } 80 \text { centimetres, the tail was only } 25 \text {; the legs were membrane- } \\
\text { coated, the jaws trimmed with several rows of teeth (...). At ten people came; after a lunch } \\
\text { where we tasted the roast otter meat, we had to get going"... }\end{array}$ & $\mathrm{U} / \mathrm{B}$ \\
\hline
\end{tabular}



the fjord, because of some fierce animals they called "water tigers", which always attacked and ate anything in the river. They described them as yellow quadrupeds, bigger than the puma. "... that animal must be the large, dark otter with an orangey chest that exists in Paraná; but the tale of the Indians is curious because it relates to the name of the lake: Nahuel Huapi or "isle of the tigers."

Moreno (1897).

De Rosales (1878).

\section{Prichar}

(2003).

7 Chehébar C, Ramilo E (1992).
1876-1877 "... in the rivers in the interior there's a Lutra that the Indians call the "water tiger". I have a treated pelt that the Mapuches gave me in Caleufú, they said they had caught it south of Tequel Malal, that is, in Chubut; it's the Lutra chilensis or huillín, which had not been seen before in that part of Patagonia. In the Chubut river they are very rare and in the Negro river they are not abundant either: they are known as "lobitos de agua".(water wolves, a local name for otters)

1878 "... among the amphibian animals we have seen here, one is called Guillin by the Indians, and its lifelike and perfect portrait shows on their stamps and descriptions by Conrad Gesnero, with the name of Lutria, which the Spanish call Otter. It is reddish-brown in colour, the fur is soft, the teeth yellow and sharp, the tail long and covered in fur. It fishes and fills its caves with fish in a short time, it bites with such tenacity that it doesn't relax the pressure until you hear the sound of bones breaking. Their pelts are very warm, of great use for the headaches produced by the cold and to correct paralysis". Their bile makes marvellous eye drops against the clouds and cataracts of the eyes". They shelter close to the rivers and freshwater lagoons. Many say that it is a species of beaver, and that it shares qualities with it.

1900-1901 “... in the Patagonian region there are countless skins with very silky fur, which are in great demand for the manufacture of luxury overcoats.......very little has been done about this. The ones that stand out are: guanaco, grey, red, and Magellanic fox, huillín or lobito de rio, the hare, huemul, and pampas deer."

".. I saw a huge pile of skins of these impressive animals, which had been hunted there..."

a) "... the huillín has been, and still is, an animal that for the Indians has magical power of great strength, employed only to revive exhausted reproductive capacity or to increase existing capacity", b) "... the contact of certain animals also transfers to the Mapuche some physiological properties he is lacking. This happens with rubbing the charred genital organs of the huillín (Lutra huidobra) on various parts of the body, which has the virtue of renovating regenerative strength in the elderly." 


\section{The Mapuche origin of the name Lontra provocax}

The Mapuche name "huillín" appears as the common name of this species in all the publications analysed, revealing the continuity of the name over time. This is not a minor detail, since many animal names have been replaced by others in Spanish.

According to the bibliography analysed, the origin of the common name "huillín" has been little studied except for in the work of Chehébar and Ramilo (1992), who briefly mentioned "its name comes from the Araucanian word (attributed to the Mapuches) "huyli" which means nail or claw, because of its welldeveloped claws". The existing Mapuche language dictionaries we consulted did not describe the etymology of the word, just that the word is "huillín"/willín, and its meaning: otter (Table 2).

The testimonies of key people and the IDYCPA experts indicate that the etymology of the word huillín (= willin, williñ, guillín) is wil' i, which in the
Mapuche language means nail, or claw; the "n" at the end means the person who has, or who is. This not only coincides with the claws presented by the species, but also with the idea about its character and the role it plays in the natural systems it inhabits: it's a feisty species, with a strong personality, which faces up to other species or forms of life. This description speaks of with the ecological role of the species as a top predator (Kruuk 2006; Mason and MacDonald 2009; Chehébar and Ramilo 1992).

\section{The huillín as a zootoponym}

As regards the zootoponyms found (Table 3), $100 \%$ corresponded to the diverse aquatic environments inhabited by the species: wetlands, gullies, lakes and flood meadows. In all cases it was mentioned that the huillín lived there, sharing the area with the people who talk about it. Of the total number of zootoponyms found, $87.5 \%(n=7)$ were Chilean, and $12.5 \%(n=1)$ were Argentine. 
Table 2. Descriptions of the "huillín" in dictionaries.

\begin{tabular}{|c|c|c|c|}
\hline $\mathbf{N}^{\circ}$ & Bibliographicalreference & Name found & Referred to as... \\
\hline 1 & Lenz, R. (1910) & huillín & $\begin{array}{l}\text {..."an otter appreciated for its fur ( } L u- \\
\text { tra huidobra), "guillin"... }\end{array}$ \\
\hline 2 & Augusta, F.J.D. (1916) & williñ & "the otter (Lutra huidobra)" \\
\hline 3 & Valenzuela, P. A. (1918). & huillín & "an otter of the country" \\
\hline 4 & Erize, E. (1960). & huillín & $\begin{array}{l}\text { "lagoon otter" Lutra provocax. Syn- } \\
\text { onvm: luü-lüu. }\end{array}$ \\
\hline 5 & Sánchez, C. R. (1988) & huillín & "willín, the otter" \\
\hline 6 & $\begin{array}{l}\text { Hernández Sallés, A., Pizarro, N.R. y } \\
\text { Luna, C.C. (2002). }\end{array}$ & williñ & "huillín, otter" \\
\hline 7 & Díaz-Fernández, A. (2006) & williñ & huillín (Lutra huidobra) \\
\hline 8 & Díaz-Fernández, A. (2009) & huillín & $\begin{array}{l}\text { "... the williñ (Lutra huidobra) another } \\
\text { species of 'otter'. }\end{array}$ \\
\hline 9 & Malvestitti, M., Orden M.E.(2014) & williñ & 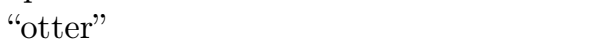 \\
\hline 10 & Villena Araya, B. (2017). & williñ & "otter" \\
\hline 11 & Mouchard, A. (2019) & Lontra provocax & "huillín" \\
\hline
\end{tabular}


Table 3. Record of zootoponyms associated with the huillín

\begin{tabular}{|c|c|c|c|c|c|}
\hline $\mathbf{N}^{\circ}$ & Zootoponym & Georeference & Location & Meaning & Bibliographicalreference \\
\hline 1 & Locality Huillín & $\begin{array}{l}35^{\circ} 15^{\prime} 18.73^{\prime \prime S} \\
72^{\circ} 14^{\prime} 10.04^{\prime \prime} \mathrm{W}\end{array}$ & $\begin{array}{l}\text { Constitución, in the Maule Re- } \\
\text { gion of Chile. }\end{array}$ & willin: otter & Villagrán 1999, Lenz 1910 \\
\hline \multirow[t]{2}{*}{2} & $\begin{array}{l}\text { Lake and Locality } \\
\text { Huillinco/Willinko }\end{array}$ & $\begin{array}{l}42^{\circ} 40^{\prime} 15.67 " \mathrm{~S} \\
73^{\circ} 53^{\prime} 28.56^{\prime \prime} \mathrm{W}\end{array}$ & $\begin{array}{l}\text { Chonchi, in Los Lagos Region of } \\
\text { Chile, on Chiloé Island. }\end{array}$ & willin: otter, ko: water, wetlands & Villagrán 1999 \\
\hline & & $\begin{array}{l}38^{\circ} 8^{\prime} 6.75^{\prime \prime S} \\
73^{\circ} 14^{\prime} 28.15^{\prime \prime} \mathrm{W}\end{array}$ & $\begin{array}{l}\text { Contulmo, in theBío Bío Region } \\
\text { ofChile. }\end{array}$ & & \\
\hline 3 & $\begin{array}{l}\text { Section of wetlands } \\
\text { Llahuillin }\end{array}$ & $\begin{array}{l}40^{\circ} 33^{\prime} 56.68^{\prime \prime} \\
\mathrm{S}^{\circ} 3^{\circ} 13^{\prime} 36.86^{\prime \prime} \mathrm{W}\end{array}$ & $\begin{array}{l}\text { Osorno, in Los Lagos Region of } \\
\text { Chile. }\end{array}$ & Llag: half, willin: otter & Villagrán 1999, Ramírez 1995 \\
\hline 4 & $\begin{array}{l}\text { Zone Tranawillín/ } \\
\text { Tranahuillin }\end{array}$ & $\begin{array}{l}38^{\circ} 39^{\prime} 0.12^{\prime \prime} \\
\mathrm{S} 72^{\circ} 47^{\prime} 25.15^{\prime \prime} \mathrm{W}\end{array}$ & $\begin{array}{l}\text { Sector of approximately } 1000 \\
\text { hectares in Cholchol, in the } \\
\text { Araucania Region of Chile. }\end{array}$ & $\begin{array}{l}\text { Trann: fall williñ: otter ("huillín } \\
\text { thrown out") }\end{array}$ & González 1944 \\
\hline 5 & Wetlands Millahuillin & $\begin{array}{l}39^{\circ} 38^{\prime} 35^{\prime \prime} \\
\mathrm{S}^{\prime} 2^{\circ} 56^{\prime} 20^{\prime \prime} \mathrm{W}\end{array}$ & $\begin{array}{l}\text { Valdivia, in the Los Ríos Region } \\
\text { of Chile. }\end{array}$ & $\begin{array}{l}\text { Milla: gold huillín: otter "Otter } \\
\text { of gold" }\end{array}$ & $\begin{array}{l}\text { https://www.mindat.org/feature- } \\
\text { 3878561.html }\end{array}$ \\
\hline 6 & Wetlands Huillinlebu & $\begin{array}{l}38^{\circ} 18^{\prime} 15^{\prime \prime} \\
\mathrm{S}^{\prime} 2^{\circ} 18^{\prime} 35^{\prime \prime} \mathrm{W}\end{array}$ & $\begin{array}{l}\text { Malleco, in the Araucania Re- } \\
\text { gion of Chile. }\end{array}$ & $\begin{array}{l}\text { Lebu: river huillín: otter "Otter } \\
\text { river" }\end{array}$ & $\begin{array}{l}\text { Gonzalez } 1944 \text {, } \\
\text { https://www.mindat.org/feature- } \\
\text { 3887524.html }\end{array}$ \\
\hline 7 & Cove Caleta huillín & $\begin{array}{l}40^{\circ} 23^{\prime} 15.77^{\prime \prime} \\
\mathrm{S} 73^{\circ} 45^{\prime} 16.07^{\prime \prime} \mathrm{W}\end{array}$ & $\begin{array}{l}\text { San Juan de la costa, in Los La- } \\
\text { gos Region of Chile. }\end{array}$ & $\begin{array}{l}\text { Cala(s): a small coastal opening, } \\
\text { smaller than a bay huillín: otter }\end{array}$ & http://es.getamap.net/mapas \\
\hline 8 & Lake Nahuel Huapi & $\begin{array}{l}40^{\circ} 55^{\prime} 32.22^{\prime \prime} \\
\mathrm{S} 71^{\circ} 30^{\prime} 54.24^{\prime \prime} \mathrm{W}\end{array}$ & $\begin{array}{l}\text { Nahuel Huapi National Park, Ar- } \\
\text { gentina. }\end{array}$ & $\begin{array}{l}\text { Nahuel: "water tiger" (huillín), } \\
\text { Huapi: island. }\end{array}$ & $\begin{array}{ll}\text { Fonck } 1896, & \text { Musters } \\
\text { Biedma } 1964\end{array}$ \\
\hline
\end{tabular}


According to Villagrán and Videla (2018), the Mapuche people consider that each place is endowed with a spirit as an expression of power, represented by an animal that is revered. This is why zootoponyms associated with the huillín show the strong bond that existed between this species and the Mapuche people, and the places they lived in, in harmonious interaction.

The Argentine case is found in Lake Nahuel Huapi, and it should be pointed out that there are several hypotheses as to the meaning of the name of this lake, one of which may involve the river otter. Fonck (1896) reported that "Lagoon Nahuelhuapi has three small islands in it, and one larger one called Nahuelhuapi, from which the name has been taken for the lake itself and for the mission, and all the land surrounding it. This name means "isle of the tiger", but its origin is not known. It could be deduced that the American tiger or jaguar (Panthera onca) gave its name to the island and surrounding lands, if it did reach these latitudes in distant times.

We do not have enough data on this fierce inhabitant of the jungles and intertropical fields, whose homeland, as is generally assumed, does not currently pass from the latitude of Buenos Aires and is therefore far from Nahuel Huapi and of the territory inhabited by the Araucana (Mapuche) nation" (Figure 4a). According to Biedma (1967), in the Mapuche language Nahuel means tiger and Huapi means island, peninsula or forest clearing. As to its origin, he says "we can only guess, since there are no tigers in the zone", referring to Panthera onca. Lenz (1895) drew attention to the widespread diffusion in the Araucanian language of this word "nahuel", meaning tiger; it figures in toponyms and surnames even though it refers to an animal which was unknown in Chile and did not reach as far south as Nahuel Huapi in Argentina.

Musters (2007) thought that the animal living on the island was not the jaguar (Panthera onca), but rather the "water tiger", the huillín. Fonck (1896) supported this hypothesis, questioning why the "Araucanians" (Mapuches) would name a place after a species that lived so far away. He thought it probable that the huillín was abundant in Nahuel Huapi, a hypothesis also mentioned by Biedma (1967). In this context, in our work we follow the hypothesis of Musters and Fonck, since this river otter is present in Lake Nahuel Huapi and it would make complete sense for its name to refer to this species.

\section{The huillín as a patronym}

The river otter does not seem to be a common patronym among the Mapuche peoples (Villagrán 1999). According to this author, $33 \%$ of the patronyms cited refer to names of mammals, and only
6\% $(n=2)$ are associated with the huillín: 1) Currihuillín - kurüwillín: kurü: dark colour, willín: river otter, and 2) antüwillín: antü: sun, willín: river otter. The first refers to the dark colour of this species (their back is dark), and the second refers to the habit the huillín has, like other otters, of sunbathing on the rocks (Mason and MacDonald 2009).

\section{CONCLUSION}

This work has brought together valuable information on LEK, from the past and the present, relating to the river otter. Huillín, the name for Lontra provocax in the Mapuche language, has prevailed in the scientific literature as the common name of the species, showing its importance in the biocultural patrimony of Patagonia and its intimate relationship with the Mapuche people.

Analysis of its etymology reveals a top predator, feisty and territorial, with an aquatic lifestyle. Its character is also mentioned in other sources - by researchers who carried out ecological studies of the species, in several ethnohistorical texts written by individuals who had direct contact with the otter, and by the man who put the word provocax in the animal's scientific name (Thomas 1908). Nevertheless, the detail given by LEK about its name in the Mapuche language, which refers to the use of its claws, and the power this gives to the animal, shows the completeness of the interpretation made by the Mapuche people of an animal that plays a key role in their aquatic ecosystems.

With regard to the huillín as a zootoponym, most examples have been found in Chile. In both cases (Chilean and Argentine), reference is made to sites where people lived alongside the huillín, in the past and in the present. In Argentina there is only one case, that of Lake Nahuel Huapi, whose meaning "isle of the tiger" could refer to the huillín, this being the only zootoponym found so far that has lasted over time. Up to now, local inhabitants and authorities have erroneously spoken of the name of the lake as referring to the jaguar (Panthera onca), and the presence of this species at these latitudes in the past. There are no records to show that its distribution ever reached as far south as Lake Nahuel Huapi, but it did reach the coastal area of Rio Negro and Chubut provinces (Figure 4a). The reinterpretation of this zootoponym makes a lot of sense since lake Nahuel Huapi belongs to Nahuel Huapi National Park, whose emblem features the huillín (Figure 4b). This may mean that the ecological and emblematical importance of the huillin for the area was first recognised by the Mapuche people.

The striking absence of zootoponyms in north Patagonia could be due to the renaming process that 


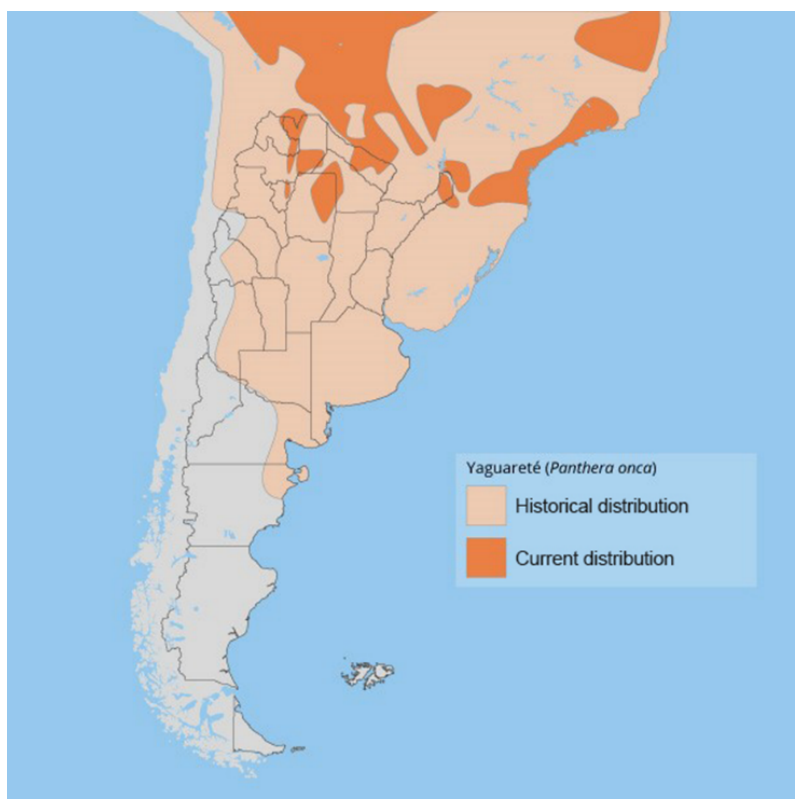

$\mathbf{a}$

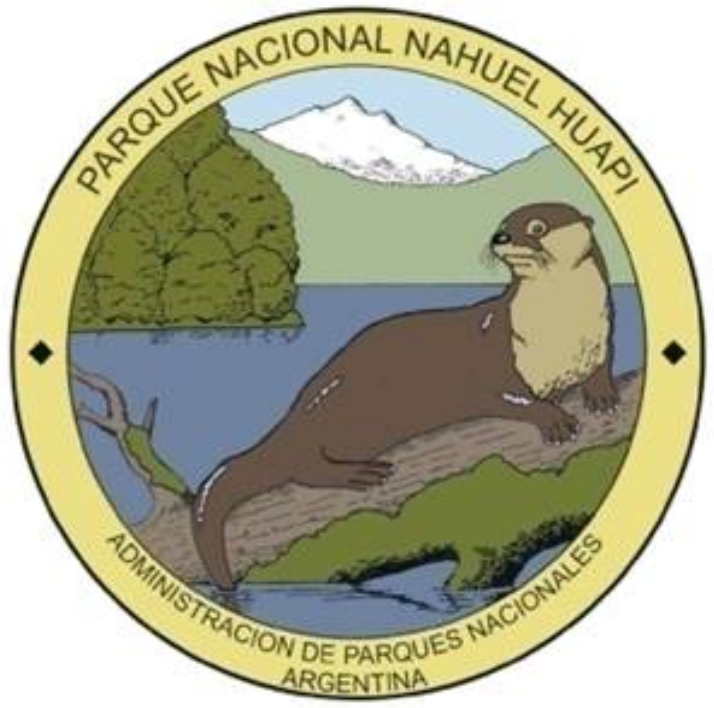

b

Figure 4. Local zootoponym and the huillín (Lontra provocax). a. Historical and current distribution of the jaguar (Panthera onca) adapted from https://felinosdeargentina.com.ar/los-felinos/gato-andino/yaguaretemapa-distribucion b. The emblem of Nahuel Huapi National Park, featuring the huillín.

took place after the Conquest of the Desert military campaign, when local names were explicitly replaced with names of Jesuits who had been "heroes" of the campaign, or of people who had been involved in that process. The conquest of the desert was a strong military offensive carried out by the Argentine State at the end of the $19^{\text {th }}$ century, which led to the genocide of a large part of the Mapuche population (Lenton et al. 2015; Delrío 2017). This is comparable with processes of similar characteristics that have occurred throughout the world with indigenous communities (Day 2006).

Christopher Columbus, for example, did not hesitate to give names inspired by religion, or his Spanish patrons, in order to ensure sovereignty (Day 2006). Francisco Pascasio Moreno, also known as Perito Moreno (1852-1919), was an Argentine scientist, naturalist, conservationist, politician, botanist, explorer and geographer. He considered that the places he visited had no previous names, or that he could rename them, since ". . science had the right to choose names to show its conquest of virgin lands" (Moreno 1897). This is shown by maps published from 1897 until today, originally drawn up by him and then replicated, up to the present time.

The ethnozoological aspects of this species have been little studied, which shows the importance of investigating further, to register, for example, the knowledge of current inhabitants of the area. Nevertheless, the biocultural legacy of the Mapuche people, which has been reinterpreted here through analysis of nomenclature, not only reveals a profound connection between the species, the people and the aquatic environments, but also a possible time path of invisibilisation of these bonds. The absence of more local toponymy, which has been systematically replaced by the State, has indirectly exacerbated the knowledge vacuum that exists regarding this species. The results of this work enable us to learn more about the biocultural heritage of our region and reflect on the associated historical and political processes. We believe that this research protocol can serve ethnozoological studies in other parts of the world, with the aim of reverting the silencing of local ecological knowledge in indigenous communities.

\section{ACKNOWLEDGEMENT}

We would especially like to thank Lorenzo Loncon and Kalfu Rayen for their substantive contribution to the manuscript. Also Dr. Marisa Malvestitti and Dr. Pablo Arias. From the Patagonia Museum a special thanks to Dr. Eduardo Bessera, Mr. Eduardo Perez, Marta Romero and Eduardo Morgenstein. Thank to Erik Müller for the final version of Figure 3. The authors also acknowledge with gratitude the comments made by the anonymous reviewer on the earlier version of this paper. This investigation was supported by the Consejo Nacional de Investigaciones Científicas y Técnicas (CONICET) of Argentina (PIP 0723). 
Pozzi and Ladio 2021. The southern river otter (Lontra provocax): insights from the perspective of Andean Patagonian ethnozoology

Ethnobio Conserv 10:20

\section{DATA AVAILABILITY}

The literature used to support the findings of this study are available from the corresponding author upon reasonable request.

\section{CONFLICT OF INTEREST}

The authors have no conflicts of interest to declare.

\section{CONTRIBUTION STATEMENT}

Conceived of the presented idea: AL.Carried out the data analysis: CP, AL Wrote the first draft of the manuscript: CP, AL. Review and final write of the manuscript: AL, CP. Supervision: AL.

\section{REFERENCES}

Aigo J, Ladio A (2016) Traditional Mapuche ecological knowledge in Patagonia, Argentina: fishes and other living beings inhabiting continental waters, as a reflection of processes of change. Journal of ethnobiology and ethnomedicine $12: 56$

Alves R, Alves H (2011) The faunal drugstore: Animal-based remedies used in traditional medicines in Latin America. Journal of Ethnobiology and Ethnomedicine 7(9).

Alves RDN, Souto WMS (2010) Etnozoologia: conceitos, considerações históricas e importância. A etnozoologia no Brasil: importância, status atual e perspectivas 7:19-40.

Alves R, Souto WMS, Oliveira REMCC, Barboza RRD, Rosa IL (2013) Aquatic Mammals Used in Traditional Folk Medicine: A Global Analysis. In: Alves RRN, Rosa I (eds) Animals in Traditional Folk Medicine. Springer, Berlin, Heidelberg pp. 241261.

Astorga C, Benavides M, Sepúlveda M, Bartheld JL, Medina-Vogel G (2006) Variables de paisaje y su relación con la distribución del huillín en las cuencas del río Toltén y Queule. In: MH Cassini, M Sepúlveda (eds) El Huillín Lontra provocax: Investigaciones sobre una nutria patagónica en peligro de extinción 1 ed. Publicación de la Organización PROFAUNA, Buenos Aires, Argentina, pp. 79-83.

Aued MB, Chéhebar C, Porro G, Macdonald DW, Cassini MH (2003) Environmental correlates of the distribution of southern river otters Lontra provocax at different ecological scales. Oryx $37: 413-421$.
Augusta FJD (1916) Diccionario araucano. Cerro Manquehue, Santiago, Chile.

Berkes F, Colding C, Folke C (2000) Rediscovery of traditional ecological knowledge as adaptive management. Ecological Applications 10:12511262.

Biedma J (1967) Toponimia del Parque Nacional Nahuel Huapi. Dirección General de Parques Nacionales, Buenos Aires.

Botello F, Salazar JM, Illoldi-Rangel P, Linaje M, Monroy G, Duque D, Sánchez-Cordero V (2006) Primer registro de la nutria neotropical de río (Lontra longicaudis) en la Reserva de la Biosfera de Tehuacán-Cuicatlán, Oaxaca, México. Revista mexicana de biodiversidad 77:133-135.

Calmé S, Sanvicente M (2009) Distribución, uso de hábitat y amenazas para la nutria neotropical (Lontra longicaudis annectens): un enfoque etnozoológico. In: Espinoza AJ, Islebe GA, Hernández HA (eds) El Sistema Ecológico de la Bahía de Chetumal/Corozal: Costa Occidental del Mar Caribe. El Colegio de la Frontera Sur, Chetumal, México, pp.124-130.

Carmanchahi P, Funes M, Bongiorno M, Monsalvo O (2006) Actualización de la distribución del huillín en la provincia del Neuquén. In: MH Cassini, M Sepúlveda (eds) El Huillín Lontra provocax: Investigaciones sobre una nutria patagónica en peligro de extinción 1 ed. Publicación de la Organización PROFAUNA, Buenos Aires, Argentina, pp.105-111.

Cassini MH, Fasola L, Chehébar C, Macdonald DW (2010) Defining conservation status using limited information: The case of Patagonian otters Lontra provocax in Argentina. Hydrobiologia 652:389-394.

Cassini MH, Sepúlveda M (2006) El Huillín Lontra provocax: investigaciones sobre una nutria patagónica en peligro de extinción. Serie Fauna Neotropical, 1 ed. Publicación de la Organización PROFAUNA, Buenos Aires, Argentina.

Cassini MH (1997) Relaciones espaciales entre el huillín Lutra provocax y el vison Mustela vison: existe competencia interespecifica. Technical Report, Administración de Parques Nacionales, Buenos Aires, Argentina.

Castillo L, Ladio A (2017) Traditional veterinary solutions for herders living in limited and changing conditions: A case study of "crianceros" of Central Northern. Journal of Arid Environments 145:90-101.

Chanin PR, Jefferies DJ (1978) The decline of the 
otter Lutra lutra L. in Britain: an analysis of hunting records and discussion of causes. Biological Journal of the Linnean Society 10:305-328.

Chébez J (1994) Los que se van, especies Argentinas en peligro. Editorial Albatros, Buenos Aires, Argentina.

Chehébar C, Porro G (1998) Distribución y estatus del Huillín (Lutra provocax) en el Parque Nacional Nahuel Huapi, Argentina. Vida Silvestre Neotropical 7:3.

Chehébar C, Ramilo E (1992) Fauna del Parque Nacional Nahuel Huapi. Administración de Parques Nacionales, Argentina.

Chehébar C, Martín S (1989) Guía para el reconocimiento microscópico de los pelos de los mamíferos de la Patagonia. Doñana Acta Vertebrata 16:247-291.

Chehébar C, Benoit I (1988) Transferencia de conocimientos para la identificación de signos de actividad y hábitats del huillín o nutria del río, Lutra provocax. Oficina Regional de la FAO para América Latina y el Caribe.

Chehébar C, Gallur A, Giannico G, Gottelli M, Yorio P (1986) A survey of the southern river otter Lutra provocax in Lanín Puelo and Los Alerces National Parks, Argentina and evaluation of its conservation status. Biological Conservation 38:293-304.

Chehébar C (1985) A survey of the Southern River Otter Lutra provocax Thomas in Nahuel Huapi National Park. Argentina. Biological Conservation 32: 299-307.

Choupay U (2006) Dieta y hábitat del Huillín en la región de Aysén, Chile. In: Cassini MH, Sepúlveda M (eds) El Huillín Lontra provocax: Investigaciones sobre una nutria patagónica en peligro de extinción 1 ed. Publicación de la Organización PROFAUNA, Buenos Aires, Argentina, pp. 55-64.

Ciafrani C, Broennimann O, Loy A, Guisan A (2018) More than range expose: Global otter vulnerability to climate change. Biological Conservation, 221, 103-113.

Costa Neto EM, Alves RRN (2010) Zooterapia: Os Animais na Medicina Popular Brasileira. 1 ed. NUPEEA, Recife, PE, Brazil.

Cox GE (2005) Viaje en las rejiones septentrionales de la Patagonia (1862-1863). 1a ed. Elefante Blanco, Buenos Aires, Argentina.

Day D (2006) Conquista: una nueva historia del mundo moderno. Editorial Crítica, Barcelona.
Delrío WM (2017) Estado y pueblo Mapuche en Argentina. Anales de la Universidad de Chile 13:133-151.

De Rosales D (1878) Historia general de el reyno de Chile, Flandes indiano. Vol. 3. Impr. del Mercurio.

Descola P (1996) La selva culta: simbolismo y praxis en la ecología de los Achuar (Vol. 17). Editorial Abya Yala.

Díaz-Fernández A (2009) "Préstamos léxicos del mapuzungun en el español de Chubut". In: Virkel A (ed) Huellas, Revista del ILLPAT, $n^{\circ} 2$. Trelew: Facultad de Humanidades y Ciencias Sociales, Universidad Nacional de la Patagonia ISSN 1851- 4421, pp. 37-53.

Díaz-Fernández A (2006) Estrategias en la traducción de algunos lexemas del mapuzungun de Chubut al castellano. In: Hipperdinger Y (ed) Lenguas en contacto en el Sur argentino. EdiUNS, Bahía Blanca, pp. 95-151.

Di Caudo MV (2016) Interculturalidad y educación desde el Sur. Contextos, experiencias y voces. Revista Entornos 29:465-466.

Erize E (1960) Diccionario comentado mapucheespañol,[español-mapuche]; araucano, pehuenche, pampa, picunche, rancülche, huilliche. Editorial Yepun, Buenos Aires, Argentina.

Fasola L (2009) Distribución, alimentación e interacciones de dos mustélidos semiacuáticos en los bosques andino patagónicos: el Huillín (Lontra provocax), nativo, y el Visón Americano (Mustela vison), introducido. Tesis doctoral. Universidad de Buenos Aires, Argentina.

Fasola L, Chéhebar C, Porro G, MacDonald D, Cassini MH (2006). Distribución actual del huillín en la Argentina. In: Cassini MH, Sepúlveda M (eds) El Huillín Lontra provocax: Investigaciones sobre una nutria patagónica en peligro de extinción 1 ed. Publicación de la Organización PROFAUNA, Buenos Aires, Argentina, pp. 98-104.

Fita DS, Neto EMC, Cano-Contreras EJ (2009) El quehacer de la etnozoología. Manual de Etnozoología: una guía teórico práctica para investigar la interconexión del ser humano con los animales.Tundra, España.

Frake C (1969) Struck by speech: the Yakan concept of litigation. Law in culture and society. In: Nader (ed) Aldine Publishing Co, Chicago, pp. $147-68$.

Fonck F (1896) Viajes de fray Francisco Menén- 
Pozzi and Ladio 2021. The southern river otter (Lontra provocax): insights from the perspective of Andean Patagonian ethnozoology

Ethnobio Conserv 10:20

dez a la Cordillera. Valparaiso, Chile: Niemeyer.

Gomez JJ, Gozzi AC, Macdonald DW, Gallo E, Centrón D, Cassini MH (2010) Interactions of exotic and native carnivores in an ecotone, the coast of the Beagle Channel, Argentina. Polar Biology 33:1371-1378.

González G (1944) "Las reliquias de Arauco". Anales de la Universidad de Chile: 5556.

Gonzalez Lagos C (2006) Dieta del huillín (Lontra provocax) en el humedal de Boroa, IX Región, Chile. Tesis Doctoral, Universidad Austral de Chile, Chile.

Gozzi AC (2008) Composición de la alimentación del huillín, Lontra provocax en Bahía Lapataia Tierra del Fuego. Tesis de licenciatura Universidad Nacional de Luján, Buenos Aires, Argentina.

Guevara T (1927) El pueblo mapuche. Editorial Andujar.

Hajek F, Groenendijk J (2001) Manejo del turismo de naturaleza en hábitat del lobo de río (Pteronura brasiliensis) en el sureste del Perú. El Manu y otras experiencias de investigación y manejo de bosques neotropicales. APECO, INRENA, PROMANU, MAB, UNESCO. Cusco-Perú 101-109.

Hartmann HN (2018) Procesos de clasificación del mundo animal y vegetal en Mapuzungun. Cuadernos de la Alfal Nº 10 mayo 2018: 135-147 ISSN 2218- 0761

Hartmann HN (2016) Arbitrariedad y motivación en el léxico etnobiológico del mapuche. Tesis Doctoral. Facultad de Humanidades y Ciencias de la Educación, Argentina.

Hermann TM, Schüttler E, Benavides P, Gálvez N, Söhn L, Palomo N (2013) Values animal symbolism and human-animal relationships associated to two threatened felids in Mapuche and Chilean local narratives. Journal of Ethnobiology and Ethnomedicine 9:41.

Hernández Sallés A, Pizarro NR, Luna CC (2002) Mapuche. Lengua y cultura. Diccionario mapudungun-español-inglés. Santiago de Chile: Maitén/Pehuén/Universidad Católica de Temuco, Chile.

Jefferies DJ (1989) The changing otter population of Britain 1700-1989. Biological Journal of the Linnean Society 38:61-69.

Kruuk H (2006) Otters: ecology, behaviour and conservation. Oxford University Press.

Lariviére S (1999) Lontra provocax. Mammalian Species (610):1-4.

Lenton DI, Delrio WM, Pérez P, Papazian AER., Nagy MA, Musante M (2015) Huellas de un genocidio silenciado: los indígenas en Argentina. Universidad del Museo Social Argentino, Conceptos 493:119-142.

Lenz R (1910) Diccionario etimológico. Santiago: Universitaria.

Lenz R (1895) Estudios araucanos: viaje al pais de los manzaneros: contado en dialecto huilliche por el indio Domingo Quintuprai, de Osorno. Anales de la Universidad de Chile 359-385.

Levy-Strauss C (1972) "Mitológicas". México: FCE.

Medeiros MFT (2009) Etnobotánica histórica: princípios e procedimentos. NUPEEA. Núcleo de Publ. em Ecología e Etnobotânia Aplicada.

Macdonald SM, Mason CF (1985) Otters, their habitat and conservation in Northeast Greece. Biological Conservation 31(3):191-210.

Macdonald SM, Mason CF (1984) Otters in Morocco. Oryx 18:157-159.

Macdonald SM, Mason CF (1983) Some factors influencing the distribution of otters (Lutra lutra). Mammal review 13:1-10.

Macdonald SM (1983) The status of the otter $\mathbf{L u}$ tra lutra in the British Isles. Mammal Rev. 13:1123.

Malvestitti M, Orden ME (2014) Günün a yajütshü: el Vocabulario Puelche documentado por Roberto Lehmann-Nistsche. EUNLPam, Editorial de la Universidad Nacional de La Pampa.

Malvestitti M (2005) Kiñe Rakizuam: textos mapuche de la Línea Sur. Universidad de Buenos Aires. Facultad de Filosofía y Letras. Instituto de Lingüística.

Martínez I (2009) Naturaleza-cultura. Un marco de análisis para la relación persona-cosmos. Anales de Antropología (Vol. 43).

Mason CF, Macdonald SM (2009) Otters: ecology and conservation. Cambridge University Press.

Mason CF, Macdonald SM (1987) The use of spraints for surveying otter Lutra lutra populations: an evaluation. Biological Conservation 41:167-177. 
Pozzi and Ladio 2021. The southern river otter (Lontra provocax): insights from the perspective of Andean Patagonian ethnozoology

Ethnobio Conserv 10:20

Mauri, M, Elli T, Caviglia G, Uboldi G, Azzi M (2017) RAWGraphs: A Visualisation Platform to Create Open Outputs. In: Proceedings of the 12th Biannual Conference on Italian SIGCHI Chapter, New York, NY, USA: ACM, pp. 28:1-28:5.

Medeiros MFT (2014) Procedures for documentary analysis in the establishment of ethnobiological information. In: Albuquerque UP, Cunha LVFC, Lucena RFP, Alves RRN (eds) Methods and techniques in ethnobiology and ethnoecology. Humana Press, New York, NY, pp. 75-85

Medina-Vogel G, Barros M, Organ JF, Bonesi L (2013) Coexistence between the southern river otter and the alien invasive North American mink in marine habitats of southern Chile. Journal of Zoology 290:27-34.

Medina-Vogel G, Gonzalez-Lagos C (2008) Habitat use and diet of endangered southern river otter Lontra provocax in a predominantly palustrine wetland in Chile. Wildlife Biology 14:211-220.

Medina-Vogel G, Kaufman VS, Monsalve R, Gomez V (2003) The influence of riparian vegetation, woody debris, stream morphology and human activity on the use of rivers by southern river otters in Lontra provocax in Chile. Oryx 37:422430 .

Medina G (1998) Seasonal variations and changes in the diet of southern river otter in different freshwater habitats in Chile. Acta Theriologica 43:285-292.

Medina G (1997) A comparison of the diet and distribution of southern river otter (Lutra provocax) and mink (Mustela vison) in southern Chile. Journal of Zoology 242:291-297.

Medina G (1996) Conservation and status of $\mathbf{L u}$ tra provocax inoccurrence of river otters by habitat on Mount Desert Island, Chile. Pacific Conservation Biology 2:414-419.

Medina G (1991) The status of the Huillín ( $L u$ tra provocax) in Chile. Proceedings V. International Otter Colloqium Hankenbüttel 1989. Habitat 6:63-69.

Melquist WE, Hornocker MG (1979) Methods and techniques for studying and censusing river otter populations. University of Idaho, Forest, Wildlife and Range Experiment Station.

Melquist WE, Whitman JS, Hornocker MG (1981) Resource partitioning and coexistence of sympatric mink and river otter populations. In: Chapman JA, Pursley P (eds) Proceedings of the worldwide furbearers conference. Donnely and Sons
Co Forstburg, Maryland, pp. 187-221.

Melquist WE (1982) Ecological aspects of a river otter (Lutra Canadensis) population in westcentral Idaho.

Miotti LL, Salemme MC (2004) Poblamiento, movilidad y territorios entre las sociedades cazadoras-recolectoras de Patagonia. Complutum 15:177-206.

Molina GI (1987) Ensayo sobre la historia natural de Chile, Bolonia 1810. Ediciones Maule.

Moreno (1897) Apuntes preliminares sobre una excursión a los territorios de Neuquén, Rio Negro, Chubut y Santa Cruz. Talleres de publicaciones del Museo, La Plata, Buenos Aires, Argentina.

Mosquera-Guerra F, Morales-Betancourt D, Páez M, Rodríguez-Ovalle G, Ramírez-Delgado JP, Pachón A (2015) Capítulo IV: Principales amenazas de la nutria neotropical (Lontra longicaudis) en el departamento de La Guajira, Colombia https://www.researchgate.net/publication/295920103.

Mouchard A (2019) Etimología de los nombres científicos de los mamíferos de Argentina. 1a ed. Fundación de Historia Natural Félix de Azara, Buenos Aires, Argentina.

Musters GC (2007) Vida entre los patagones: un año de excursions desde el estrecho de Magallanes hasta el Río Negro: 1869-1870. 1 ed CONTINENTE, Buenos Aires, Argentina.

Nagulu V, Srinivasulu C, Rao V (1999) Status of otters in Southern Indian States. An udpedate report. Envis Bulletin: Wildlife and protected areas. Mustelids, viverrids and herpestids in India. Wildlife Institute of India, Dehradun 2:71-73.

Pike R (1954) Language in relation to a united theory of the structure of human behavior, Glendale. AZ: Summer Institute of Linguistics.

Porro G, Chehébar C (1995) Monitoring the distribution and status of southern river otter ( $L u$ tra provocax) in Nahuel Huapi national Park, Argentina. International Union for the Conservation of Nature, Otter Specialist Group Bulletin 13:32-34.

Posey DA (1999) Cultural and Spiritual Values of Biodiversity. In Cultural and Spiritual Values of Biodiversity. Intermediate Technology Publications, London on behalf of UNEP.

Pozzi C, Chehébar C (2013) Distribución del huillín (Lontra provocax) en el Parque Nacional Nahuel Huapi - 2011. Revista Macroscopia: Di- 
vulgación técnico científica del patrimonio natural y cultural del Parque Nacional Nahuel Huapi. Administración de Parques Nacionales 3:22-29

Prates L (2009) El uso de recursos por los cazadores-recolectores pos hispánicos de Patagonia continental y su importancia arqueológica. Relaciones de la Sociedad Argentina de Antropología 34:201-229.

Prichard H (2003) En el corazón de la Patagonia. Ed. Zagier and Urruty Publications.

Ramírez C (1995) Onomástica Indígena de Chile: Toponimia de Osorno, Llanquihue, Chiloé. Universidad Austral de Chile, Valdivia, Chile.

Reid DG, Melquist WE, Woolington JD, Noll JM (1986) Reproductive effects of intraperitoneal transmitter implants in river otters. The Journal of wildlife management 92-94.

Reyes-Küppers RR (2007) Ecology and behaviour of the Southern river otter Lontra provocax Thomas 1908 in Chile. Tesis Doctoral, Osnabrück University, Osnabrück, Alemania.

Rodríguez-Jorquera I, Sepúlveda MA (2011) Trophic spatial variations in the Southern river otter, Lontra provocax, in freshwater habitats, Chile. IUCN Otter Specialist Group Bulletin 28:7075 .

Rozzi R (2016) Bioética global y ética biocultural. Cuadernos de Bioética 27(3): 339-355.

Rozzi R (2004) Implicaciones éticas de narrativas yaganes y mapuches dobre las aves de los bosques templados de sudamérica austral. Ornitología Neotropical 15:435-444.

Sepúlveda MA, Valenzuela AEJ, Pozzi C, MedinaVogel G, Chehébar C (2015) Lontra provocax (Lista Roja de Especies Amenazadas 2011 de la UICN). Red List. Accessed 06 February 2020.

Sepúlveda MA, Singer RS, Silva-Rodríguez EA, Eguren A, Stowhas P, Pelican K (2014) Invasive American mink: Linking pathogen risk between domestic and endangered carnivores. EcoHealth 11:409-419.

Sepúlveda MA, Bartheld JL, Meynard C, Benavides M, Astorga C, Parra D, Medina-Vogel G (2009) Landscape features and crustacean prey as predictors of the Southern river otter distribution in Chile. Animal Conservation 12:522-530.

Sepúlveda MA, Bartheld JL, Monsalve R, Gómez V, Medina-Vogel G (2007) Habitat use and spatial behaviour of the endangered Southern river otter (Lontra provocax) in riparian habitats of Chile: Conservation implications. Biological Conservation 140:329-338.

Shaler W (1990) Diario de un viaje entre China y la Costa Noroeste de América efectuado en 1804. Universidad Iberoamericana

Sielfeld W (2006) Biología y Conservación del huillín en los canales magallánicos de Chile In: Cassini MH, Sepúlveda M (eds) El Huillín Lontra provocax: Investigaciones sobre una nutria patagónica en peligro de extinción 1 ed. Publicación de la Organización PROFAUNA, Buenos Aires, Argentina pp. 46-53.

Sielfeld W, Castilla JC (1999) Scientific knowledge and conservation status of otters in Chile. Estud Oceanol 18:69-79.

Sielfeld W (1984) Hábitos alimentarios del huillín (Lutra provocax) (Mammalia, Carnívora, Mustelidae) en el medio marino de Chile Austral. Seminario de Investigación Licenciado en Ciencias. Facultad de Ciencias, Escuela de Ciencias. Universidad Austral de Chile, Chile.

Sielfeld W, Venegas C, Atalah A (1977) Antecedentes acerca de la conserva- ción y manejo de mamíferos marinos en Magallanes. ANS INST PAT, Punta Arenas (Chile) 8:297-315.

Thomas O (1908) On certain African and South American otters. Annals and Magazine of Natural History 8:387-395. v

Towei D E (1974) Winter food habits of river otters in western Oregon. The Journal of Wildlife Management, 107-111.

IUCN (International Union for Conservation of Natura) (2015) Lontra provocax. The IUCN Red List of Threatened Species. Version 2021-1.

Ulloa A (2001) Transformaciones en las investigaciones antropológicas sobre naturaleza, ecología y medio ambiente. Revista Colombiana de Antropología 37:188-232.

Vargas GC, Urrutia X (2004) Léxico de la pesca artesanal puntarenense en el Golfo de Nicoya. Una aproximación etnográfico-semántica en Chomes, Costa de Pájaros, Isla Chira y Puntarenas Centro. Káñina Rev Artes y Letras, Univ Costa Rica. 28:179-190

Valenzuela PA (1918) Glosario Etimológico de nombres de hombres, animales, plantas, ríos y lugares, y de vocablos incorporados en el lenguaje vulgar, aborígenes de Chile, y de algún otro país americano. Imprenta Universitaria, Vol. I y II. Santiago de Chile, Chile.

Valenzuela AEJ, Raya Rey A, Fasola L, Schiavini A (2013) Understanding the inter-specific dynam- 
ics of two co-existing predators in the Tierra del Fuego Archipelago: The native southern river otter and the exotic American mink. $B i$ ological Invasions 15:645-656.

Valenzuela AE, Rey A, Schiavini A (2011) Native southern river otter (Lontra provocax) versus invasive American mink (Neovison vison) in Beagle Channel, Tierra del Fuego. Actas de la 96.

Valenzuela AE (2010) Ecología y distribución del visón americano (Neovison vison) en Tierra del Fuego: efectos de este predador exótico en la fauna nativa. Mastozoologia Neotropical 17:329-331.

Vilela A, Bolkovic ML, Carmanchahi P, Cony M, De Lamo D, Wassner D (2009) Past, present and potential uses of native flora and wildlife of the Monte Desert. Journal of Arid Environments 73:238-243.

Villagrán C, Videla M (2018) El Mito Del Ori- gen En La Cosmovisión Mapuche de La Naturaleza: Una Reflexión En Torno a Las Imágenes de de Filu-Filoko-Piru. Magallana 46:249266.

Villagrán C, Villa R, Hinojosa F, Sánchez G, Romo M, Maldonado A,Caviares L, Latorre C, Cuevas J, Castro S, Papic C, Valenzuela A (1999) Etnozoología mapuche: Un estudio pre-liminar. Revista Chilena de Historia Natural 72:595-627.

Villena Araya B (2017) Diccionario araucanoespañol y español-araucano de Fray Félix José de Augusta. Universidad Católica de Temuco, Chile.

Received: 30 July 2020

Accepted: 27 February 2021

Published: 14 April 2021 